UDC 378.147:37.091.113]:[001.895:008]:378.22

Dmytro Kozlov

Sumy State Pedagogical University named aftre A.S. Makarenko ORCID ID 0000-0003-1875-0726

DOI 10.24139/2312-5993/2020.02/077-089

\title{
METHODOLOGICAL SUPPORT FOR THE INNOVATIVE CULTURE DEVELOPMENT OF THE FUTURE MANAGER OF THE GENERAL SECONDARY EDUCATION INSTITUTION IN THE MASTER'S TRAINING PROCESS
}

The methodological support for the innovative culture development of the future manager of the general secondary education institution in the master's training process is characterized. It is found out that the use of the forms and methods presented in the article in the educational process of the magistracy promotes forming in the future manager of the general secondary education institution of a susceptibility to innovation as the individual strategy, reflected in its implementation in all spheres of activity, creating the mechanism for effective organization management, ensuring the high level development of innovative processes involving the institution staff.

Key words methodological support, problem-based lectures, binary lectures, pressconferences, hackthon, quest, workshops, Google Classroom, innovative culture development, future manager, general secondary education institution, master's preparation process.

Introduction. According to scientific sources and an analysis of the higher education institutions practice (Vasianovych, 2013; Liannoi, 2015), it can be concluded that there is a tendency to decrease the informative function of traditional teaching methods and weaken its role in the the master's training program, since there is a large amount of information available and students, entering the magistracy, are experienced in relevant positions. In addition, reducing the number of lectures in the context of the introduction of the ECTS in training organization encourages teachers increasing the effectiveness of traditional teaching methods and combining them with innovative and up to date.

Consequently, there is a need for a comprehensive research analysis of the methodological support for the innovative culture development of the future manager of the general secondary education institution in the master's training process.

Analysis of relevant research. There have been numerous studies done, and papers written, among them there are V. Bereka, V. Bespalko, O. Yeremenko, O. Lozova, Yu. Liannoi, N. Nychkalo, O. Pometun, O. Semenog, O. Shapran, L. Shtefan S. Vitvytska, who have made a lot of research on the phenomenon of the higher education development, that should focus on updating the content base preparing the future manager of the general secondary education institution in the master's training process, development of the specialists' ability to adapt to high rates of scientific and technological progress, formation of the master with the creative professional thinking, development of the specialists' ability to "fold" accruing streams of 
professionally meaningful messages to readily accessible volumes, enhancing professional mobility of the graduate of the higher education institution.

Thus, the issues of the methodological support for the innovative culture development of the future manager of the general secondary education institution in the master's training process are becoming relevant nowadays.

The aim of the article - to characterize methodological support for the innovative culture development of the future manager of the general secondary education institution in the master's training process.

Research Methods: solving the highlighted aim, a set of methods of scientific research adequate to them were used, theoretical: a comparative analysis of the scientific definitions of methodological support for the innovative culture development of the future manager of the general secondary education institution in the master's training process, a systematic analysis of traditional and innovative methodological support for the innovative culture development of the future manager of the general secondary education institution in the master's training process.

Results. In the activity of the modern teacher of the pedagogical university there should be dominated by a student-centered, personal-developmental strategy of education and training involving the collaborative technologies and teaching methods use. The main characteristic of such strategy is the ability to recognize a student as a self-sufficient aspiring personality achieving the better standard of living through successful activity, deserving respect and looking forward for help and support at the higher education. Therefore, it is believed that methodological support for the innovative culture development of the future manager of the general secondary education institution in the master's training process should be a symbiosis of different methodological approaches in the educational process organizing at the pedagogical university.

However, problem-based lectures, binary lectures, press-conferences, lectures with analysis of specific situations, lectures with the use of feedback technique, which were discussed at the department meetings of the internal department scientific and methodological seminar, were introduced into the preparation practice of the future managers of the general secondary education institution in the experimental study course. Their features should be considered.

The problem-based lecture is aimed at the development of students' managerial thinking in the master's program and is characterized by increasing emphasis on the following important aspects:

- focusing on the key issues, as determined by the topic of the lecture;

- outlining the material to be refined independently;

- formulating and discussing in a dialogical manner issues which, under certain circumstances, have not been adequately covered in textbooks, manuals, or have been controversial in various publications; 
- enabling the student to check the assimilation of information independently.

At the end of the lecture, the undergraduate was provided with an electronic version of it.

The lectures were, of course, accompanied by the training material presentation. The presentation of the lecture content provides realization of the visualization principle, allowing consciously to grasp the essence of the studied phenomena and processes, focusing attention on the key issues of the education content through its presentation visual diversity, stimulating memorization of the lecture material, saving time, increasing the amount of time material. While creating the lecture presentation, MS PowerPoint programs were used, the components of which were a set of slides with corresponding text, graphics, animation and sound, which accompanies the presentation of the main material of the lecture, focusing students on its main aspects.

A binary lecture, or lecture-discourse, is a continuation and development of a problem-based material presentation, but in the dialogue of either two teachers, or a teacher and the manager of the general secondary education institution. For this purpose, real situations of theoretical and practical issues discussion by two specialists were simulated. Such lecture advantages are updating of the students' knowledge of the master's program, necessary for understanding the dialogue and participation in it; creating a problematic situation, deploying a proofing system, etc. that forces to compare different perspectives, take one of them, or form your own. Such lecture promotes development of a dialogue culture, the ability to debating, searching and making independent decisions that form the innovative culture of the future manager of the general secondary education institution.

Students' appreciation of the master's program was given by a lecture a press conference. In such lecture, the teacher invites students to ask him or her in writing questions about the topic he/she outlines. Within two or three minutes, students formulate questions, record and submit to the teacher to whom they answer. Such lecture is effective at the beginning of the study of a topic or discipline, as it allows identifying the students' interests, aspirations, opportunities in the midst of the master's program - systematizing, adjusting knowledge and finally - determining the prospects of using the education content in the management process (Nychkalo, 2016).

A lecture with the analysis of specific situations provides activation of the students' educational and cognitive activity. Such lecture involved mastering the subject's material by discussing a specific professional situation, which is presented verbally or in a video clip, illustrated, and containing sufficient information to analyze and evaluate the phenomenon and discuss it. The teacher launches a discussion around the proposed situation in order to focus 
the audience on particular professional problems, to prepare for creative perception of the education content.

A feedback lecture provides information about the extent to which the audience has mastered part of the course material by asking questions after each section. If the answer is correct, the teacher continues the presentation, if not - corrects the explanation of the lecture content, changes the teaching methods, corrects his own activity and the students' activity

During the experimental study, the following seminars types were tested, which proved themselves well:

- self-organizing seminars - give the students an opportunity to independently determine the class purpose, to distribute the work in a group, to report to the audience for the work done; to determine the prospect for the next lesson; each student chooses one topic that he or she addresses at the seminar individually or in a group;

- searching seminars - involve the students' research activities in groups, collective search for the most interesting and important problems;

- seminar - idea generator: listeners are divided into pairs: one generator, the second - organizer; the generator presents his problem vision, describes everything he knows or does not know about the problem; the organizer asks him questions for clarification, encourages speeches, records the main answers and the obtained results, which are then discussed, a speech is prepared to the audience on the results of communication;

- reflexive seminars: discuss the main results of previous lessons, analyze ways of professional activity; trainees in groups express their opinions on specific issues, the seminar coordinator captures generalized and systematic reflection results; a collective problems discussion identified during individual performances;

- seminars - excursions: are conducted according to a pre-determined plan at the object being studied (general school, lyceum, gymnasium);

- workshops: divided into repetition of theoretical material and a practical (individual or group) task. The masters group is divided into micro groups (3-5 people). The microgroup is issued a card outlining the task nature and its performance. The teacher ensures each listener's performance. The workshops varieties depend on the training material content. The issues content under discussion changes, but the structure remains largely unchanged. It depends on the teacher's individual style, his students' knowledge. Therefore, it is an extensive methodological action that has a multidimensional nature. It is advisable to conduct seminars - workshops, where the communicative, verbal and discussion skills are developed;

- seminars on the "snowball" method. Discusses problematic discussion questions that are easier to solve in a small group. It is necessary to divide the listeners into groups of 2-3 people, allowing them to discuss the problem 
within 5 minutes. The next step is to merge the two small groups, and finally, to merge the small groups into one big group, to gradually, by analyzing the complex question, gather enough material and solve the problem together;

- seminar - commented reading: a professionally selected text is selected in advance, which is read and commented upon during the reading course, explaining the basic ideas that are presented in it (Marchenko \& Kasianova, 2018).

Rapid intellectualization of the economy has set a rather large-scale task for modern higher education - forming students' ability to navigate freely in information flows, to search and process information, to independently design rational algorithms for working with it, to apply these algorithms and techniques. Therefore, introduction of the information technology into the activity of the education institution is today a priority direction for the implementation of the state educational policy.

Introduction of information technologies in the educational process allows to increase its efficiency and quality due to additional possibilities of students' cognition of the educational programs of the surrounding reality and self-knowledge, management of educational process, carrying out of monitoring (control, results correction of the educational activity, computer pedagogical testing and psychodiagnosis, scientific and methodological experience, organization of intellectual leisure, etc.

So, in the master's training process for the future managers of the general secondary education institution, we took advantage of Google services. For example, Google Classroom, which is a tool that connects Google Docs, Google Drive, Gmail, and helps creating and organizing tasks, rate, comment, and organize effective online communication with students.

In this service, teachers can easily and quickly create and check tasks that students have completed in electronic form. Students' tasks and works are automatically synthesized into a folder and document structure on disk. The Google Classroom is convenient for both the teacher and the student, as the service provides users with a versatile working device, has the user-friendly interface and capabilities required for participants in the educational process.

The features of work in the classroom are described:

1. Setting up a class. For each class, their own access key that students and other teachers use to join the community are created.

2. Integration with Google Drive. When a teacher uses Google Classroom, the Class folder is automatically created on his or her Google Drive. Students also create a Class folder with subfolders for each class to which they join.

3. Creating and distributing tasks. When creating a task in the form of a Google document, the platform creates and distributes individual copies of the document for each student in the classroom at the teacher's request, which greatly simplifies the technical aspects of the educational process. 
4. Time Limitations. When creating tasks, the teacher can specify the work term. When a student submits an assignment before the deadline is completed, his or her document displays a "Review" status allowing teachers to check the work. After the examination, the teacher can return the student's assignment for processing. It automatically goes to Edit status and the student continues to work on the document.

5. Monitoring of the tasks execution. All tasks can be monitored simultaneously, or you can control the individual tasks in several classes at once.

6. Communication in the classroom. By combining Classifieds and commenting on classroom assignments, teachers and students always keep in touch and keep track of each assignment.

So, Google Classroom was used for both lectures (such as video lectures) and seminars (seminars with the task of commenting or answering content questions, mini-forums on a given topic implemented through the comment option).

Teachers of the department introduced integrated classes from different disciplines, which were realized through methods of expressed practical character - workshops, quests, hackathons, demonstrations, presentations, etc., which formed the practical management skills, experience of management and innovative culture of the future manager of the general secondary education institution. The isolated methods are characterized.

Workshop (K. Fopel's term) - dynamic learning that occurs through the participants' active work; the emphasis is shifted to gaining dynamic knowledge; participants define the learning goals independently, sharing responsibility with the teacher for their own learning process.

Workshop is an intensive educational event, during which masters' study through their own activity, and theoretical information - minimal and play a small role. The focus is on students' independent preparation of the master's program and their active interaction (Marchenko \& Kasianova, 2018, p. 24). Workshop is associated with such concepts as: activity, experiment, risk, change, democratic decision-making, self-expression, internal change, positive interaction, which are components of the leader's innovative culture.

The duration of the workshops was varied. The most appropriate workshop form during the experiment was identified as mini-workshops that lasted an hour. Their important characteristic is diversity. A well-organized workshop provides a variety of methods that will encourage future managers to interact. On workshop training is due to the actual experience and personal experience, which is easier to perceive in group interaction. Learning during a workshop is a transformation of information into useful knowledge.

Quest (from the English quest - "search") - is a kind of innovative learning with elements of traditional (problem), which uses methods of stimulation through didactic games. 
Originally, the name quest was used in the name of the computer games developed by Sierra On-Line: King's Quest, Space Quest, Police Quest. Later, the quest began to be called active extreme and intellectual games. In 1995, a web-based quest model was introduced by San Diego University teacher Bernie Dodge as a method for making the most of the Internet during training sessions. He identified 12 types of tasks for web quests: translation, planning and design, self-discovery, compilation, creative assignment, analytical task, detective, puzzle, mysterious story, consensus building, evaluation, journalistic investigation, persuasion, scientific research (Khvysiuk et al., 2018).

The introduction of the quest during the formative phase of the experimental study allowed:

- activating mental activity by creating special conditions for tasks that require sufficient managers' awareness and maturity, the ability to overcome specially created obstacles;

- developing a stable students' interest in self-education;

- enhancing perception of the material by means of clarity;

- combining modern and traditional teaching aids;

- developing universal forms of mental activity: analysis, synthesis, induction, comparison, systematization, etc.

The main idea of the quest is the educational and cognitive activity development in conditions where all the mental processes of the listener, his attention, emotional and volitional sphere are ready for active processing of educational material.

The hackathon originates from the IT realm and comes from the two words - hack and marathon. However, the idea of intensive work on the problem gradually spread to other spheres over a limited period of time. Its use for the innovative culture development of the future manager of the general secondary education institution is conditioned by its main characteristics.

Hackathon is a training event where team members listen to a specific professional problem for a limited time. Unlike other forms of collective learning, hackathon provided the opportunity to fully immerse themselves in the professional sphere creating a specific solution to a specific management problem and present it to colleagues.

A master class was used to develop the innovative culture of the future manager of the general secondary education institution. Masterclass: master is the best in any field, class, is a modern training - form for improving managerial skills or developing management skills by different methods, technologies to systematize and generalize knowledge in the educational management, innovations, exchange of best practices, broadening of horizons, attraction to the newest branches of knowledge, which is carried out by a specialist in the management field of the education institution for students of the master's 
program, which have reached a sufficient level of problems awareness of the innovation management.

The master class represented a fundamentally developed original method, technique or copyright technology that is based on its principles and has a specific structure. In its conducting course, a direct discussion of the proposed product (method, admission, technology) was carried out and the search for a creative solution to the professional problem was carried out by the participants of the master class, as well as by the teacher or the manager of the general secondary education institution, who conducted the master class.

The undeniable positive impact of such classes was that they fully reflected and ensured such component development of the innovation culture of the future manager of the general secondary education institution, as a procedural institution, which provides the future manager with the ability to use the next generation integrated and partial programs, innovative technologies, providing education institutions with additional educational services, creating conditions that motivate professional teacher education development, corporate culture formation, search for new forms of education institution presentation, partnership of all subjects of the educational process, implementation by the manager of educational practices, exteriorization of their own orientations for innovation in the process of managing the institution, which is proper and foreseen by the developed and theoretically substantiated model.

Also, the future managers of the general secondary education institutions were invited to practice networking. Networking is a social and professional activity aimed at the fastest and most efficient solution of complex life, professional tasks and business issues with the help of a circle of friends and acquaintances (for example, finding clients, hiring the best employees, attracting investors). It should also be noted that networking involves building trust and long-term relationships with people and mutual assistance. That is, networking is the process of establishing business contacts to create relationships that can grow into a business in the future. Therefore, the students of the master's program were invited to attend business seminars, business courses outside the educational establishment, to participate in a conference, a forum on certain issues, which is conducted online, and to establish business contacts on social networks. The results of these activities were discussed at special seminars and recommendations were made regarding the use of acquired skills and established contacts in future management activities.

Nowadays, it is important for the manager of an education institution possessing self-presentation methods, since potential and actual consumers of educational services of the institution like seeing a person, a particular professional and interact with him. Parents and children, who study or choose a learning institution, are required to use information from the Internet before they visit the institution or their supervisor. Therefore, the modern manager of 
the general secondary education institution should have self-branding as a way of self-presentation, which helps to better communicate with consumers of educational services and partners, increase the level of educational services provision and expand their offer. Therefore, future supervisors were asked to create a school website that would include a photo of the supervisor and his or her address to the children, their parents, and the public. In addition, the students of the master's program during their studies have run their own block as a Headmaster and created their own pages on Instagram and Linkedin. On these pages, trainees have posted weekly posts promoting their activities, presenting their reflections on general secondary education institution, or providing useful information to the target audience.

It is not disputed that nowadays an important type of managerial activity of the manager of the general secondary education institution is financial activity. Therefore, students were asked to master crowdfunding as part of their extracurricular work. Crowdfunding - community financing is the collaboration of people who voluntarily pool their money or other resources, usually through the Internet, supporting other people's efforts, or organizations. Such funding can perform a variety of tasks, such as helping disaster victims, the sick, supporting fans or fans, supporting political parties, financing startups, creating free software, and more. This is usually a large amount of small contributions.

Today, there are many platforms for raising funds for different needs in Ukraine, so the GoFundEd platform can support educational projects from students, Komubook offers to support books and get them at a lower price, RazomGo platform supports young entrepreneurs and start-ups, Community and NaStarte platforms support projects from many categories. Dozens and hundreds of support projects are available on online platforms. You must choose an interesting project and support it for any desired or proposed amount.

Therefore, the masters were asked to either support the project or try to submit one. In order to start raising funds, it was necessary to declare the goal, to determine the cost of achieving it, and to calculate all costs and the way of financing should be open to the public freely available. Crowdfunding is not just an alternative access to funds. It gives you the opportunity to gain special experiences, positive emotions, and unexpected support from strangers or foreigners.

However, future managers of the general secondary education institution have mastered fundraising during out-of-class work.

Fundraising is the search for human, information, financial, material, and other resources pursuing targeted projects or the science of successfully convincing others that organizations activities deserve attention.

Fundraising tasks are:

- search for potential donors; 
- substantiate the needs of the organization in accordance with the interests of potential donors and their understanding of the problems;

- forming, supporting and developing relationships with potential donors;

- forming public opinion in favor of supporting the activities of the organization or staff, collecting letters of support, gaining authority.

Therefore, students in the master's program were asked to choose one of the strategies for finding resources, namely:

- extensive, which involves the creation of funds and programs databases;

- intensive, which entails careful planning and preparation of projects and the submission of grant applications to a carefully selected fund or program.

To master the fundraising methods, the students participated in:

- joint projects to obtain targeted funding for programs of international organizations. In addition to grants, students and colleges of general secondary education institutions were involved in joint projects;

- state-funded projects for social partnerships between government agencies and the non-governmental sector, developing mutual interest and understanding of the need for long-term cooperation;

- organizing special fundraising events (charity evenings, auctions, concerts, sports competitions);

- involvement of volunteers who give their time, knowledge, professional skills for the noble purposes of the organization;

- personal meetings with representatives of charitable, nongovernmental organizations, government agencies, etc.;

- use of Internet resources to host their own Web pages describing the goals and programs of the organization, etc.;

- creating advertising by posting special articles, creating and displaying videos at special events, distributing booklets, calendars, posters that reflect a particular problem that is vital;

- writing and mailing thanks letters.

Marketing in education is a management function that shapes and implements a strategy of increasing the person's value, ensures the development of the organizational personnel, and therefore, mastering it contributes to the innovative culture development of the future manager of the general secondary education institution.

For the education manager, marketing is the design, implementation, and evaluation of educational services by linking education institutions and consumers to their services in order to balance interests and meet educational needs. In addition, marketing in education meets the institution needs in the competitiveness of the educational services market and its employees' material well-being, staff development, and society - in the expanded reproduction of the country's labor and educational potential. 
Therefore, during the internship, the following managers of the general secondary education institution were offered:

- to analyze the location of the education institution, its educational and material base, public prestige, determine the teachers' rating, the level of scientific research, educational and methodological support of the educational process, the complex of related services;

- to identify potential customers' demand for educational services, competitors' educational activities, the actual status of the portfolio, and specify target consumers' groups of educational services;

- to segment the market for educational services in order to develop their own marketing tools: demand generation, communication, sales, mutual fulfillment of obligations;

- to characterize the subjects of marketing of educational services: a wide range of intermediaries (employment centers, staffing agencies, executive bodies, licensing and accreditation of education institutions, etc.), associations, public organizations and structures related to the promotion of consumer education in the educational market;

- to formulate proposals on the range of educational services, to provide for the possibility of updating it taking into account the demand of the labor market and the population; to inform, advise, participate in public licensing and accreditation of the general secondary education institution.

Conclusions. The methodological support for the innovative culture development of the future manager of the general secondary education institution in the master's training process is characterized. It is found out that the use of the forms and methods presented in the article in the educational process of the magistracy promotes the future manager of the general secondary education institution forming a susceptibility to innovation as the individual strategy, reflected in their implementation in all spheres of activity, creating the mechanism for effective organization management, ensuring the high level development of innovative processes involving the institution staff.

Prospects of the further research. The further research prospects include development of the methodological support for the implementation of the identity orientation system of the future manager of the general secondary education institution on its innovative culture development in the master's training process.

\section{REFERENCES}

Vasianovych, H. P. (2013). Methodological contexts of pedagogical science at the present stage of its development. Pedagogy and Psychology of Professional Education: A Scientific and M ethodological Journal, 3, 9-31.

Marchenko, V. H., Kasianova, O. M. (2018). M ethods of conducting and evaluating seminars in postgraduate education institutions. Kharkiv: KhM APO. 
Khvysiuk, O. M., Marchenko, V. H., Kasianova, O. M. (2018). Use of 3D-visualization technology in postgraduate medical education on the basic principles of STEM education. Kharkiv: KhMAPO.

Liannoi, Yu. O. (2015). Professional preparation of magisters in physical rehabilitation in higher educational establishments of Ukraine. Science and Education a New Dimension Pedagogy and Psychology. Budapest, 111 (29). Issue 57, 39-42.

Nychkalo, N. G. (2016). Methodological culture in the scientific growth of the teacherresearcher. Modern information technologies and innovative teaching methods in the training of specialists: methodology, theory, experience, problems. Kyiv-Vinnytsia: Planner LLC, 44, 22-29.

\section{PEЗЮME}

Козлов Дмитрий. Методическое обеспечение развития инновационной культуры будущего руководителя учреждения общего среднего образования в процессе магистерской подготовки.

Охарактеризовано методическое обеспечение развития инновационной культуры будущего руководителя учреждения общего среднего образования в процессе магистерской подготовки. Установлено, что использование представленных в статье форм и методов в образовательном прочессе магистратуры способствует будущему руководителю учреждения общего среднего образования срормировать восприимчивость к инновациям как стратегии личности, отражается в реализации их во всех срерах деятельности, создать механизм эфрективного управления организацией, обеспечить высокий уровень развития инновационных процессов с участием персонала заведения.

Ключевые слова: методическое обеспечение, проблемные лекции, бинарные лекции, лекции-пресс-конференции, хакатон, квест, воркшоп, Google Classroom, инновационная культура, будущий руководитель, заведение общего среднего образования, процесс магистерской подготовки.

\section{АНОТАЦІЯ}

Козлов Дмитро. Методичне забезпечення розвитку інноваційної культури майбутнього керівника закладу загальної середньої освіти у процесі магістерської підготовки.

3'ясовано, що в практику підготовки майбутніх керівників закладу загальної середньої освіти в ході експериментального дослідження було запроваджено проблемні лекції, бінарні лекції, лекції-прес-конференції, лекції із розбором конкретних ситуацій, лекції із застосуванням техніки зворотного зв'язку, методика проведення яких обговорювалась на засіданнях кафедри та внутрішньокафедральному науково-методичному семінарі. Важливо акцентувати увагу на тому, що запроваджено проведення інтегрованих занять із різних навчальних дисциплін, які реалізовувалися через методики вираженого практичного характеру - воркшопи, квести, хакатони, майстер-класи, демонстрації, презентації тощо, які формували саме практичні управлінські уміння і навички, досвід управлінської діяльності, а також розвивали інновачійну культуру майбутнього керівника закладу загальної середньої освіти.

Наголошено, що запровадження інформаційних технологій в освітній процес підготовки майбутніх кекрівників закладу загальної середньої освіти дозволяє підвищити його ефрективність і якість завдяки додатковим можливостям пізнання слухачами освітніх програм навколишньої дійсності і самопізнання, управління навчально-виховним процесом, проведення моніторингу (контролю, корекції результатів навчальної діяльності, комп'ютерного педагогічного тестування $i$ 
психодіагностики), поширення науково-методичного досвіду, організації інтелектуального дозвілля тощо.

Зазначимо, що у прочесі магістерської підготовки майбутніх керівників закладів загальної середньої освіти нами використано можливості Google сервісів. Приміром, Google Classroom, який є інструментом, що пов'язує Google Docs, Google Drive, Gmail i допомагає створювати та впорядковувати завдання, виставляти оцінки, коментувати й організовувати ефрективне спілкування зі студентами в режимі реального часу.

Схарактеризовано методичне забезпечення розвитку інноваційної культури майбутнього керівника закладу загальної середньої освіти у процесі магістерської підготовки. З'ясовано, що використання поданих у статmі форм і методів в освітньому процесі магістратури сприяє майбутньому керівнику закладу загальної середньої освіти сформувати сприйнятливість до інновачій як стратегії особистості, що відображається в реалізації їх у всіх сферах діяльності, створити механізм ефрективного управління організачією, забезпечити високий рівень розвитку інноваційних процесів за участю персоналу закладу.

Ключові слова: методичне забезпечення, проблемні лекції, бінарні лекції, лекції-прес-конфреренції, хакатон, квест, воркшоп, Google Classroom, інноваційна культура, майбутній керівник, заклад загальної середньої освіти, процес магістерської підготовки.

удК 796.011.3-053.67

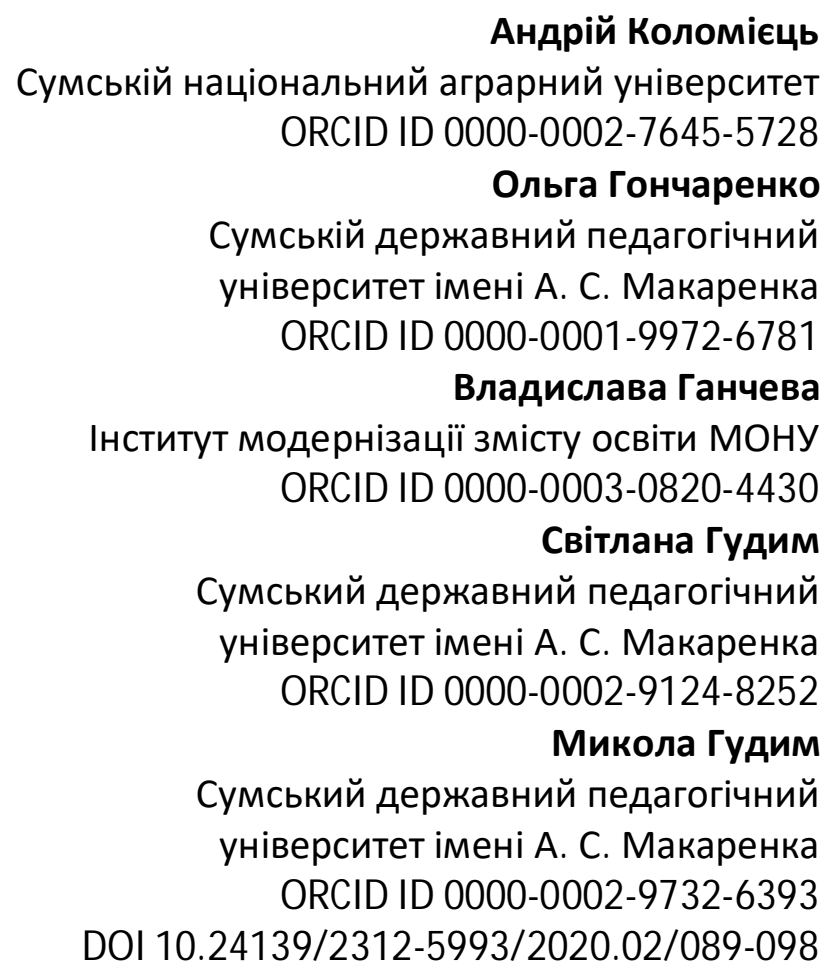

\section{ОРГАНІЗАЦІЙНО-МЕТОДИЧНІ УМОВИ ПРОВЕДЕННЯ САМОСТІЙНИХ ЗАНЯТЬ ФІЗИЧНИМИ ВПРАВАМИ ЗІ СТУДЕНТАМИ-ПЕРШОКУРСНИКАМИ}

Метою даної статmі є розробка та впровадження науково-обгрунтованої системи самостійних занять фрізичними вправами з урахуванням індивідуальних особливостей розвитку студентів-першокурсників зВО. Якісна характеристика рівня фізичної підготовленості показала, що використання запропонованих 